
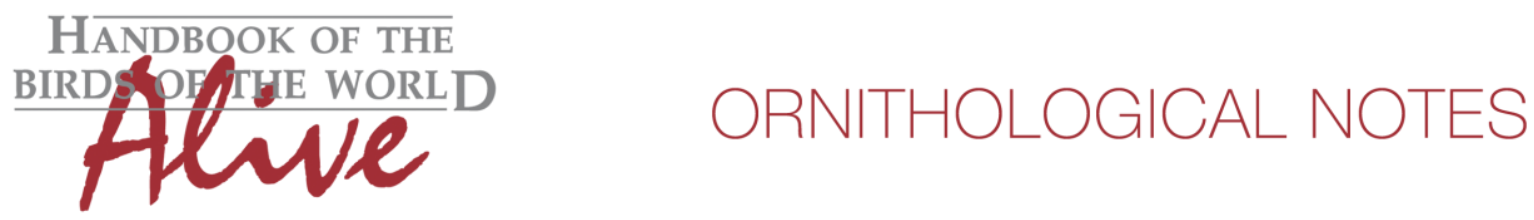

\title{
Notes on the vocalizations of Grey Elaenia (Myiopagis caniceps)
}

Peter Boesman

In the following we briefly analyze and compare voice of the different races of Grey Elaenia (Myiopagis caniceps). We also try to quantify the extent of any vocal differences using the criteria proposed by Tobias et al. (2010), as a support for taxonomic review.

We have made use of sound recordings available on-line from Xeno Canto (XC) and Macaulay Library (ML).

Voice is quite varied, and the main song-like vocalizations are a series of fairly high-pitched notes, trailing off into a descending trill, and an excited "e-e-e-e-pitchew pitchew-peechew", similar in tone quality. The latter is heard less often, and sometimes the trill changes prematurely into (part of) the second vocalization.

In the following we only analyze the 'pure and complete' first vocalization to allow for comparison. (We are thus quite selective in our choice, which may reduce the variability and over-emphasize differences)

At first sight, there is little difference in the voice of the different races, but further analysis shows some distinct features (Fig. 1):

M. c. parambae $(n=6)$

max. freq.

start freq. trill

end freq. trill

start note length

end note length

start pace

end pace

total \# notes

note shape
$5980-7040 \mathrm{~Hz}$

$5250-6080 \mathrm{~Hz}$

$3900-5200 \mathrm{~Hz}$

$0.12-0.155 \mathrm{~s}$

$0.05-0.095 \mathrm{~s}$

$0.13-0.16$

$0.07-0.12$

11-24

few spaced curly notes followed by trill of sharp dagger-shaped notes
M. c. cinerea $(n=5)$

max. freq.

start freq. trill

end freq. trill

start note length

end note length

start pace

end pace

total \# notes

note shape

$\begin{array}{lll} & \text { Cristalino recording } & \text { Fr. Guyana } \\ 5600-732 \mathrm{~Hz} & 7150 \mathrm{~Hz} & 592 \mathrm{~Hz} \\ 5500-5940 \mathrm{~Hz} & 5770 \mathrm{~Hz} & 5600 \mathrm{~Hz} \\ 3800-4870 \mathrm{~Hz} & 4100 \mathrm{~Hz} & 5300 \mathrm{~Hz} \\ 0.09-0.10 \mathrm{~s} & 0.13 \mathrm{~s} & 018 \mathrm{~s} \\ 0.09-0.10 \mathrm{~s} & 0.08 \mathrm{~s} & 0.07 \mathrm{~s} \\ 0.11-0.13 & 0.15 & 0.18 \\ 0.11-0.13 & 0.11 & 0.11 \\ 21-31 & 29 & 21 \\ \text { few fast sharp notes followed by rounded knife-shaped notes }\end{array}$

few fast sharp notes followed by rounded knife-shaped notes 


\section{HANDBOOK OF THE BIRDS PF,THE WORLD Alve}

\section{ORNITHOLOGICAL NOTES}

M. c. caniceps $(n=5)$

max. freq.

start freq. trill

end freq. trill

start note length

end note length

start pace

end pace

total \# notes

note shape
$5350-5860 \mathrm{~Hz}$

$4950-5860 \mathrm{~Hz}$

$4250-5100 \mathrm{~Hz}$

$0.095-0.14 \mathrm{~s}$

$0.04-0.045 \mathrm{~s}$

0.10-0.16

$0.05-0.06$

41-69

few overslurred notes followed by trill of overslurred notes

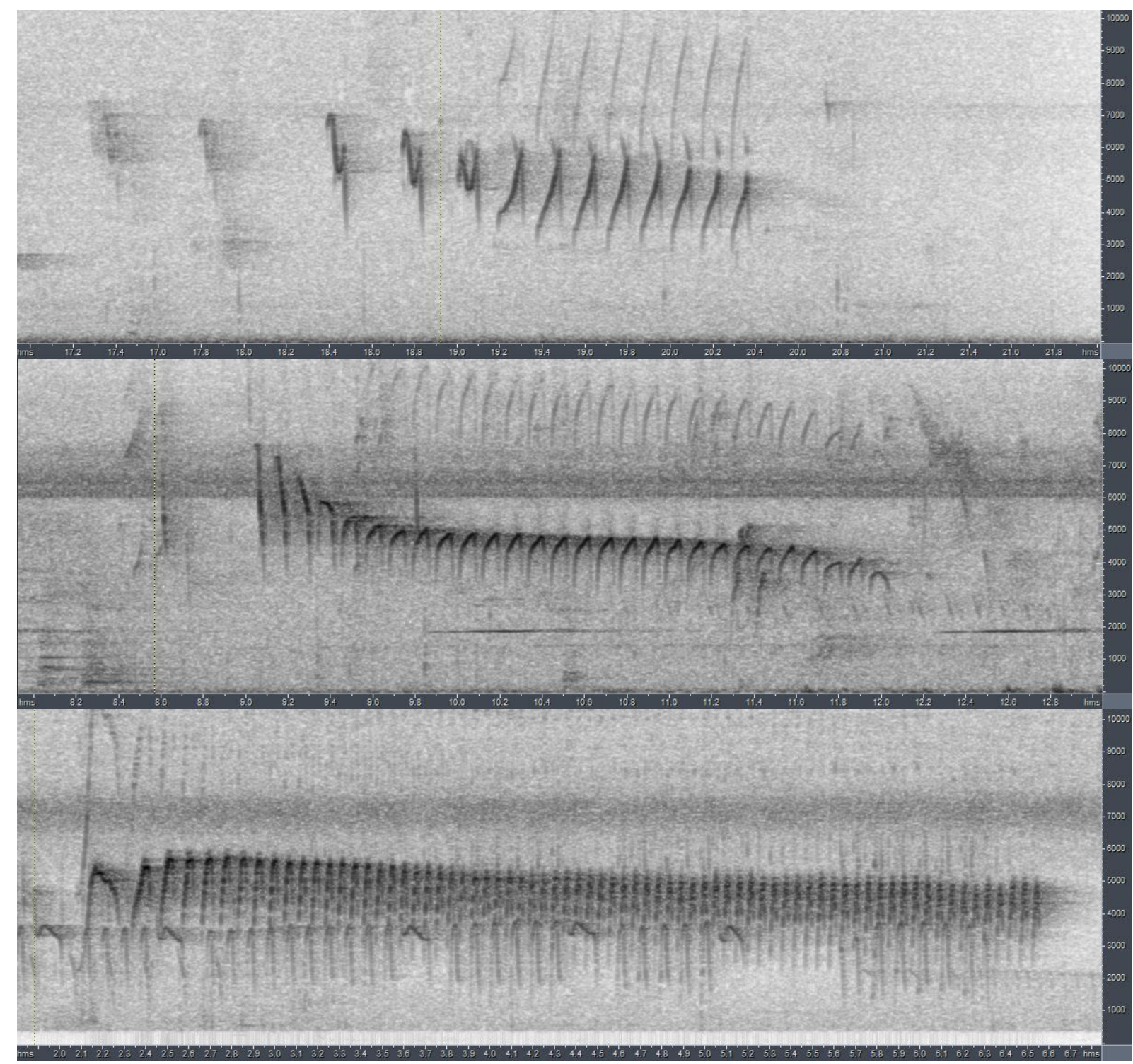

Figure 1: from top to bottom: typical song of parambae, cinerea and caniceps 

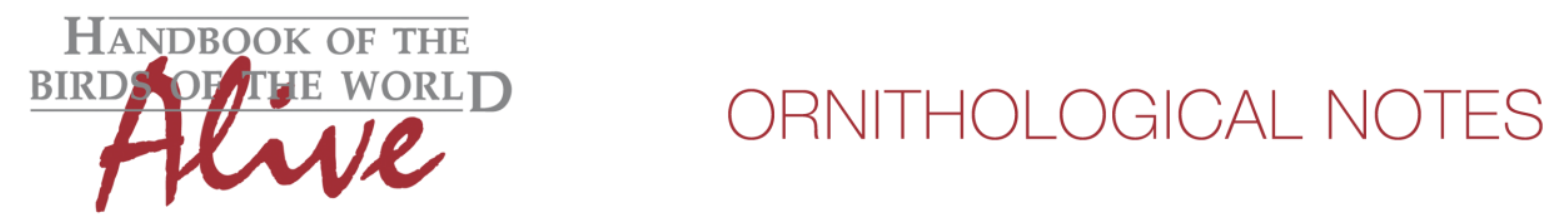

M. c. parambae has the lowest number of notes, has the longest initial notes and has a peculiar note shape readily identified on sonogram.

M. c. cinerea has short initial note length and long end note length, with hardly any change in pace over the trill.

M. c. caniceps has very short end notes, a fast end pace and a strong acceleration in pace. Also the highest number of notes (when considering only 'full trills').

Recordings from Cristalino (extreme N Mato Grosso) fit well within the western Amazonian vocal group (cinerea). A single recording from French Guyana (XC23044) is somewhat more divergent (possibly a different taxon?) but fits best with cinerea.

If we compare caniceps versus the others, we can score based on fast end pace and pace acceleration (score 2 ) and number of notes (2-3). When applying Tobias criteria, this would result in a total vocal score of 4-5.

And when comparing parambae vs. cinerea, the former has fewer notes (score 2), has a different note shape of both introductory notes and trilled notes (score 1-2), and introductory notes are well-spaced (unlike cinerea)(score 2-3). This would lead to a total vocal score of about 4.

Remains to check whether Panamanian race absita is close to parambae.

There is only 1 recording of song available from Panama, from the Canal zone (ML105069, there noted as call), which starts with a few spaced curly notes, followed by accelerating dagger-shaped notes, indeed very much like parambae (Fig. 2).

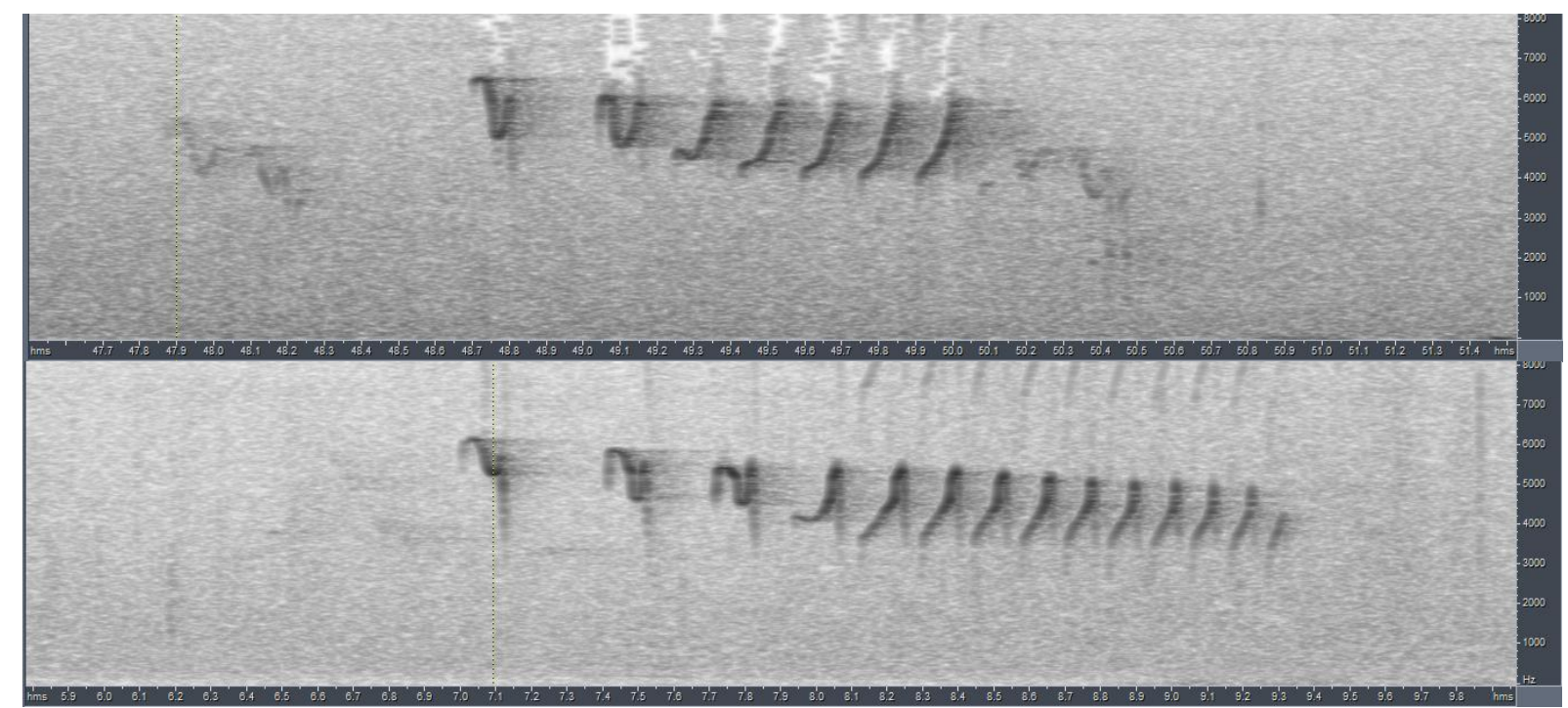

Figure 2: song of absita (ML105069, top) copared to typical song of parambae (bottom) 

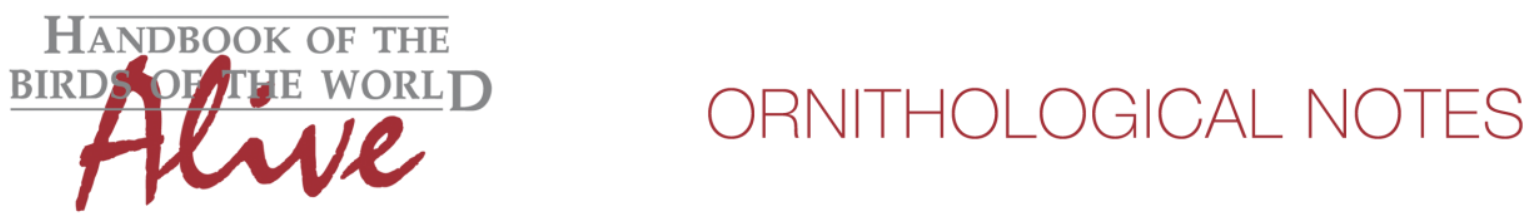

We haven't analyzed call notes, which may reveal additional vocal differences. As it is not always clear in what context the calls are given, this poses some extra challenges (some calls are actually just the introductory notes of the song (without the trill), others are different). From a quick scan however, it looks like caniceps has mainly a round overslurred note, cinerea a bisyllabic or double note, and parambae a curly note.

We can thus conclude, that based on comparison of typical song, there are clearly 3 vocal groups, which show significant differences (scores 4-5).

This note was finalized on 21th August 2015, using sound recordings available on-line at that moment. We would like to thank in particular the many sound recordists who placed their recordings for this species on XC and ML.

\section{References}

Tobias, J.A., Seddon, N., Spottiswoode, C.N., Pilgrim, J.D., Fishpool, L.D.C. \& Collar, N.J. (2010). Quantitative criteria for species delimitation. Ibis 152(4): 724-746.

\section{Recommended citation}

Boesman, P. (2016). Notes on the vocalizations of Grey Elaenia (Myiopagis caniceps). HBW Alive Ornithological Note 135. In: Handbook of the Birds of the World Alive. Lynx Edicions, Barcelona. (retrieved from http://www.hbw.com/node/932058 on 9 August 2016). 